\title{
Mean neutrophil volume is elevated in patients suffering from acute coronary syndrome.
}

\author{
Zafer Buyukterzi1 ${ }^{1}$, Kadri Murat Gurses², Sami Erdem³, Mehmet Akif Bor³, Mehmet Sertaç Alpaydın1, Ahmet Lütfü \\ Sertdemir $^{1}$, Pelin Albayrak ${ }^{1}$ \\ 1Sağllk Bilimleri Üniversitesi, Konya Eğitim Araştırma Hastanesi, Kardiyoloji Kliniği, Konya, Türkiye \\ 2Adnan Menderes Üniversitesi, Tıp Fakültesi, Temel Tıp Bilimleri Ana Bilim Dalı, Aydın, Türkiye \\ 3Sağlık Bilimleri Üniversitesi, Konya Eğitim Araştırma Hastanesi, Biyokimya Kliniği, Konya, Türkiye
}

\section{$\ddot{O} Z$}

GİRIŞ ve AMAÇ: Nötrofiller akut koroner sendromların (AKS) erken döneminde anahtar rol oynayan inflamatuvar hücrelerdir. Geçmiş çalışmalar, AKS'de dolaşımdaki nötrofil miktart ile iliş̧kili değişkenlerde artış olduğunu ortaya koymuştur. Ortalama nötrofil hacmi (ONH) nötrofil aktivasyonunun yeni bir belirteci olarak kabul edilmektedir. Bu çalışmada, AKS hastalarında ONH değerlerinin incelenmesi hedeflenmiştir.

YÖNTEM ve GEREÇLER: Mayls-Ağustos 2016 tarihleri arasında iskemi değerlendirmesini takiben stabil koroner arter hastalı̆̆ı (SKAH) ön tanısı alan ve elektif koroner anjiyografi uygulanan hastalar $(n=82)$ ile; bu hastalarla yaş ve cinsiyet açısından eşlenik, AKS nedeniyle acil koroner anjiyografi yapılan hastalar $(n=39)$ çalışmaya dahil edilmiştir. Elektif koroner anjiyografi uygulanan hastalardan 40'inda epikardiyal koroner arterler normal olarak bulunmuş ve bu hastalar kontrol grubu olarak kabul edilmiştir. Kalan 42 hasta ise SKAH grubunu oluşturmuştur.

BULGULAR: Çalışmaya toplam 121 hasta (ortalama yaş 61.18 yll, \%49.59 erkek) dahil edilmiştir. Beyaz küre sayıları $(p=0.485)$ gruplar arasında farklilık göstermemiştir. ONH değerleri, AKS grubunda hem kontrol grubuna, hem de SKAH grubuna kıyasla anlaml şekilde artmış olarak bulundu (her ikisi için $p<0.001)$. AKS hastalarında ONH değerleri ile zirve $C K-M B(r=0.572, p=0.008)$ ve Tn-I $(r=0.478, p=0.018)$ değerleri arasında anlaml pozitif korelasyon saptandı. Çok değişkenli regresyon analizinde ONH değerlerinin $A K S$ varliğ ile bağımsız ilişkisinin olduğu görüldü (OR: 1.048, 95\% CI: 1.242-1.596, $p<0.001$ ).

TARTIŞMA ve SONUÇ: Bu çallşmada elde edilen bulgular, AKS'de nötrofil sayısında değişiklik olmasa bile nötrofil kompozisyonunda değişiklikler olabileceğini öne sürmektedir. ONH değişimi ile belirlenebilen bu değişimin, AKS'nin erken tanısındaki ve AKS sonrası iskemik hasarı öngörmedeki rolü daha ileri çalışmalarla ortaya konulmalıdır.

Anahtar Kelimeler: Akut koroner sendrom, ateroskleroz, koroner arter hastalı̆̆l, ortalama nötrofil hacmi.

\begin{abstract}
INTRODUCTION: Neutrophils are the key inflammatory cells in the acute phase of myocardial infarction(MI). Parameters related to absolute or relative number of circulating neutrophils have been reported to be increased in previous studies. Mean neutrophil volume(MNV) has emerged as a new marker of activated neutrophils. In this study, we aimed to evaluate MNV in subjects suffering from myocardial infarction.
\end{abstract}

METHODS: For this purpose, we included age and gendermatched consecutive patients undergoing either elective coronary angiography following ischemia- guided assessment of patients with stable coronary artery disease $(S C A D)(n=82)$ or percutaneous coronary angiography due to MI(Group 3, $n=$ 39) between May- August 2016. Among those undergoing elective coronary angiography, 40 patients were found to have normal epicardial coronary arteries(Group 1) and remaining 42 patients were classified as SCAD group(Group 2).

RESULTS: A total of 121 subjects(mean age 61.18 years, $49.59 \%$ male) were recruited in this study. White blood cell count $(p=0.485)$ did not differ among three groups. MNV was found to be significantly elevated in Group 3 (174.80 [9.30]), compared to both Group 1 (147.40 [14.80]) ( $p<0.001)$ and 2 (162.30 [14.72]) $(p<0.001)$. MNV was also significantly higher in Group 2 when compared to Group 1( $p<0.001)$.

DISCUSSION AND CONCLUSION: Our findings suggest that neutrophil composition shows alterations in MI in the lack of quantitative changes. The spectrum of morphological changes in neutrophils, expressed in terms of $M N V$, merits further evaluation for its predictive value for early diagnosis of ACS and the extent of post-MI ischemic damage.

Keywords: Acute coronary syndrome, atherosclerosis, coronary artery disease, mean neutrophil volume.

İletişim / Correspondence:

Dr. Zafer Buyukterzi

Sağllk Bilimleri Üniversitesi, Konya Ĕ̆itim Araştırma Hastanesi, Kardiyoloji Kliniği, Konya, Türkiye

E-mail: buyukterzizafer@hotmail.com

Başvuru Tarihi: 08.12.2018

Kabul Tarihi: 02.04.2019 


\section{INTRODUCTION}

Despite advances in the prevention, diagnosis and treatment strategies, ischemic heart disease still remains to be the leading cause of morbidity and mortality worldwide(1). Acute coronary syndrome (ACS) accounts for the major cause of morbidity and mortality due to ischemic heart disease. It refers to a clinical spectrum, which ranges from unstable angina (USAP) to non-ST segment elevation myocardial infarction (NSTEMI) or ST segment elevation myocardial infarction (STEMI), which results from an acute decrease in blood supply to the coronary arteries due to a variety of reasons.

Atherothrombotic coronary artery disease is the most common cause of ACS. It is precipitated by atherosclerotic plaque rupture, which is complicated by intraluminal thrombosis, distal thrombus embolization and plaque hemorrhage(2). Since inflammation is a key player in ACS pathogenesis, the relationship between several hematological parameters and ACS has been investigated in many studies. Up to now, white blood cell (WBC) count(36 ), platelet count, mean platelet volume (MPV), neutrophil to lymphocyte ratio (NLR)(7-9), platelet to lymphocyte ratio (PLR)(10), red cell distribution width (RDW)(11) and WBC to MPV ratio (WMR)(12) have been reported to be related with ACS diagnosis and its prognosis.

Leukocytes have an essential role in the progression of atherosclerosis and in atherosclerotic plaque rupture, leading to thrombotic adverse events. Neutrophils are the key inflammatory cells in the acute phase of myocardial infarction (MI)(13). Parameters related to absolute or relative number of circulating neutrophils have been reported to be increased in the setting of MI in previous studies (4, 14). Mean neutrophil volume (MNV) has emerged as a new marker of activated neutrophils. In this study, we aimed to evaluate MNV in subjects suffering from ACS.

\section{MATERIAL AND METHODS}

\section{Study population}

Age and gender- matched consecutive patients undergoing either elective coronary angiography following ischemia-guided assessment of patients with stable coronary artery disease $(\mathrm{SCAD})(\mathrm{n}=82)$ or emergent coronary angiography due to ACS ( $\mathrm{n}=$ 39) between May 2016- August 2016 have been included in this study. Patients were scheduled for coronary angiography following detailed evaluation for suspected ischemic heart disease in case of positive non- invasive ischemia evaluation. Patients who were admitted to emergency department and diagnosed with acute coronary syndrome (ACS) underwent primary PCI. Patients with a prior diagnosis of chronic kidney disease, chronic inflammatory disease (such as rheumatologic, hematological, or other autoimmune diseases), infectious disease, malignancies were not included in the study. Sociodemographic characteristics, comorbidities (such as hypertension, diabetes mellitus), and medications were recorded in all patients. Laboratory examinations included complete blood count, renal function tests, and lipid profile. Additionally, creatine kinase-myocardial band (CK- MB) and troponin- I (Tn-I) levels were checked in patients diagnosed with ACS. Transthoracic echocardiography was performed in all patients to record left ventricular ejection fraction (LVEF). Study was conducted in accordance with the Helsinki Declaration and approved by the local ethics committee (GO: 2016/ 524). Written consent was obtained from all patients prior to involvement.

\section{Measurement of MNV}

Ten milliliters of peripheral venous blood samples were obtained from patients prior to coronary angiography. For the measurements of MNV, Beckman Coulter LH 750 analyzer (Beckman Coulter, Fullerton, CA, USA) was used. This device is a routine hematology analyzer, which classifies blood cells via whole-blood analysis using spectrophotometry, electrical impedance and laser light scattering.

\section{Statistical analysis}

Normally distributed continuous parameters are presented as mean \pm standard deviation, and skewed continuous parameters are expressed as median (interquartile range defined as the difference between twenty-fifth and seventy-fifth percentiles). Categorical data are presented as frequencies and percentages, and compared with chi- square test. Normally distributed continuous parameters were compared among 3 groups using one- way analysis of variance (ANOVA) test with Bonferroni correction. Skewed data from 3 patient groups were 
compared with the Kruskal-Wallis $\mathrm{H}$ test followed by the adjusted Mann-Whitney U test. Comparison of 2 groups was made with the Student t- test and the Mann-Whitney $U$ test for parameters with and without normal distribution, respectively. Pearson and Spearman correlation analyses were done to investigate the relationship between MNV and other parameters with and without normal distribution, respectively. Multinomial logistic regression analysis was performed to determine the independent associates of ACS occurrence. Statistical analyses are performed using SPSS statistical software version 21.0 (SPSS Inc., Chicago, Illinois). A 2-tailed $\mathrm{p}<0.05$ is considered statistically significant.

\section{RESULTS}

A total of 121 subjects (mean age 61.18 years, $49.59 \%$ male) were recruited in this study. Following elective coronary angiography, 40 subjects were found to have normal epicardial coronary arteries (group 1, G1), whereas the remaining 42 subjects had stable atherosclerotic coronary artery disease (group 2, G2). Among 39 patients who underwent PCI due to ACS (group 3, G3), 18 had STEMI and 21 had NSTEMI.

Prevalence of hypertension, diabetes mellitus, smoking and family history of coronary artery disease were similar in all groups (all $\mathrm{p}>0.05$ ). Body mass index (BMI), serum creatinine, fasting blood glucose, lipid profile parameters and LVEF did not differ between groups (all $\mathrm{p}>0.05$ ). White blood cell count was similar in all groups ( $p>0.05$ ), whereas MNV was significantly elevated in G2 ( $<<0.001)$ and G3 ( $\mathrm{p}<0.001$ ) compared to G1 and G3 compared to $\mathrm{G} 2(\mathrm{p}<0.001)$. CRP was also significantly elevated in $G 2(p<0.001)$ and $G 3(p<0.001)$ compared to G1. Baseline characteristics of the study population are given in Table 1.

MNV levels did not differ in subjects with or without hypertension, diabetes mellitus or family history of coronary artery disease. MNV levels were also similar in both genders, as well as smoker and non-smokers. Comparison of MNV levels regarding presence of conventional cardiovascular risk factors is shown in Table 2.

Among baseline characteristics, only peak CKMB ( $\mathrm{r}=0.527, \mathrm{p}=0.008)$, Tn-I $(\mathrm{r}=0.478, \mathrm{p}=0.018)$ and CRP $(\mathrm{r}=0.308, \mathrm{p}=0.002)$ levels were significantly correlated with MNV levels. Correlation between baseline characteristics and MNV levels is shown in Table 3.

In the multivariate regression analysis model including family history of coronary artery disease, MNV, CRP and LVEF for identifying associates of ACS, only MNV (odds ratio [OR]: 1.408, 95\% confidence interval $[\mathrm{CI}]: 1.242-1.596)$ and CRP (OR: 1.092, 95\% CI: 1.010-1.182) levels were found to be independently associated with ACS presence compared to normal coronary arteries (Table 4).

\section{DISCUSSION}

Multiple parameters of neutrophil activity in ACS patients, such as NLR, neutrophil-specific micro particles, neutrophilic granular protein (neutrophil elastase, myeloperoxidase, and matrix metalloproteinase) and neutrophil extracellular trap release, and interactions with tissue factor, have been investigated(15).MNV has emerged as a new marker of activated neutrophils. Our study shows elevated MNV in SCAD and ACS patients compared to controls. Elevation in MNV is not only noted when compared to subjects with normal coronary arteries, but also in ACS patients compared to SCAD patients. In addition, the elevation in MNV is found to be present when adjusted for traditional CV risk factors. MNV correlates with CK-MB and Tn-I in ACS patients, as well as CRP levels, suggesting that MNV could reflect inflammation-based cardiac damage following MI.

Predictive role of several hematological markers in various cardiac diseases have been investigated in many studies $(16,17)$. Most of these studies have concentrated on inflammatory cell counts and overlooked morphological variations of these cell types especially in acute conditions such as ACS. Mean neutrophil volume depicts the average size of the circulating neutrophil population. Changes in MNV have been shown to be associated with increased inflammatory response and suggested to be a marker of disease severity in infectious diseases(18-21) and trauma(22), independent of neutrophil count. Morphological changes in the neutrophil population, reflected with the changes in $\mathrm{MNV}$, may occur due to an altered circulating neutrophil composition during ACS. 
Table 1. Baseline characteristics of the study population

\begin{tabular}{l|l|l|l|l}
$\begin{array}{l}\text { Total } \\
\text { population } \\
(n=121)\end{array}$ & $\begin{array}{l}\text { Normal } \\
\text { coronary }\end{array}$ & $\begin{array}{l}\text { Stable coronary } \\
\text { artery disease } \\
(n=42)(G 2)\end{array}$ & $\begin{array}{l}\text { Acute coronary } \\
\text { syndrome } \\
(n=39)(G 3)\end{array}$ & p value \\
& $(\mathrm{G} 1)$ & &
\end{tabular}

\section{Demographic characteristics}

\begin{tabular}{|c|c|c|c|c|c|}
\hline Age, years & $61.18 \pm 10.47$ & $61.27 \pm 12.18$ & $60.59 \pm 11.34$ & $61.57 \pm 8.94$ & 0.920 \\
\hline Gender: male n $(\%)$ & $60(49.59)$ & $19(47.50)$ & $21(50.00)$ & $20(51.28)$ & 0.737 \\
\hline \multicolumn{6}{|c|}{ Conventional risk factors for CAD } \\
\hline Hypertension n (\%) & $68(56.20)$ & $23(57.50)$ & $18(42.86)$ & $27(69.23)$ & 0.303 \\
\hline Diabetes mellitus n (\%) & $51(42.15)$ & $16(40.00)$ & $16(38.10)$ & $19(48.72)$ & 0.438 \\
\hline Smoking n (\%) & $20(16.53)$ & $5(12.50)$ & $6(14.29)$ & $9(23.08)$ & 0.209 \\
\hline $\begin{array}{l}\text { Family history of CAD n } \\
(\%)\end{array}$ & $31(25.62)$ & $9(22.50)$ & $7(16.67)$ & $15(38.46)$ & 0.108 \\
\hline Body mass index, $\mathrm{kg} / \mathrm{m}^{2}$ & $25.83 \pm 3.34$ & $26.09 \pm 4.32$ & $25.37 \pm 3.45$ & $25.12 \pm 2.16$ & 0.459 \\
\hline \multicolumn{6}{|l|}{ Laboratory parameters } \\
\hline Serum creatinine $(\mathrm{mg} / \mathrm{dL})$ & $0.95(0.31)$ & $0.86(0.28)$ & $0.95(0.42)$ & $1.06(0.31)$ & 0.271 \\
\hline $\begin{array}{l}\text { Fasting blood glucose } \\
(\mathrm{mg} / \mathrm{dL})\end{array}$ & $104.00(38.00)$ & $88.00(21.50)$ & $107.00(43.00)$ & $107.00(50.00)$ & 0.310 \\
\hline LDL- cholesterol (mg/dL) & $119.00(51.00)$ & $118.64(41.42)$ & $129.00(85.28)$ & $118.27(65.00)$ & 0.472 \\
\hline HDL- cholesterol (mg/dL) & $38.00(12.37)$ & $34.00(14.32)$ & $35.00(17.66)$ & $38.48(15.00)$ & 0.891 \\
\hline Triglyceride, $\mathrm{mg} / \mathrm{dL}$ & $142.00(79.00)$ & $149.00(88.75)$ & $140.00(99.00)$ & $128.00(78.00)$ & 0.821 \\
\hline Total cholesterol, mg/dL & $173.00(57.25)$ & $163.00(32.00)$ & $188.00(69.00)$ & $174.00(59.00)$ & 0.499 \\
\hline Hemoglobin (g/dL) & $14.05 \pm 1.95$ & $14.37 \pm 1.43$ & $14.71 \pm 2.50$ & $14.87 \pm 1.91$ & 0.725 \\
\hline $\begin{array}{l}\text { White blood cell count } \\
\left(\times 10^{3} / \mu \mathrm{L}\right)\end{array}$ & $8.00(2.80)$ & $9.50(4.13)$ & $7.70(3.30)$ & $8.70(1.90)$ & 0.485 \\
\hline Platelet count $\left(\mathrm{x}^{2} \mathbf{3}^{3} / \mu \mathrm{L}\right)$ & $\begin{array}{l}243.00 \\
(102.50)\end{array}$ & $251.50(84.75)$ & $260.00(117.00)$ & $217.00(90.00)$ & 0.368 \\
\hline $\begin{array}{l}\text { Mean neutrophil volume, } \\
\text { arbitrary units }\end{array}$ & $163.70(21.40)$ & $147.40(14.80)$ & $162.30(14.72)$ & $174.80(9.30)$ & $<0.001 * \neq \phi$ \\
\hline C- reactive protein $(\mathrm{mg} / \mathrm{L})$ & 7.73 (16.99) & $2.92(6.73)$ & 8.68 (16.49) & $13.77(29.35)$ & $0.001^{* \neq}$ \\
\hline \multicolumn{6}{|c|}{ Echocardiographic parameters } \\
\hline LVEF, \% & $60.00(10.00)$ & $62.50(8.00)$ & $56.00(10.00)$ & $59.00(21.00)$ & 0.194 \\
\hline \multicolumn{6}{|c|}{$\begin{array}{l}\text { CAD coronary artery disease, CK- MB creatine kinase- myocardial band, HDL high- density lipoprotein, LDL low- density lipoprotein, } \\
\text { LVEF left ventricular ejection fraction. Data is represented as either mean } \pm \text { standard deviation or median (interquartile range) as } \\
\text { appropriate. } \\
* p<0.05\end{array}$} \\
\hline
\end{tabular}

\section{Table 2. Comparison of MNV levels regarding presence of conventional cardiovascular risk}

factors.

\begin{tabular}{|c|c|c|c|}
\hline Variables & & MNV & $\mathrm{p}$ value \\
\hline \multirow[t]{2}{*}{ Gender: male } & - & $163.00(21.45)$ & \multirow[t]{2}{*}{0.748} \\
\hline & + & $163.70(20.12)$ & \\
\hline \multirow[t]{2}{*}{ Hypertension } & - & $159.55(20.72)$ & \multirow[t]{2}{*}{0.242} \\
\hline & + & $166.00(19.20)$ & \\
\hline \multirow[t]{2}{*}{ Diabetes mellitus } & - & $161.50(22.70)$ & \multirow[t]{2}{*}{0.321} \\
\hline & + & $166.05(14.88)$ & \\
\hline \multirow[t]{2}{*}{ Smoking } & - & $162.90(21.40)$ & \multirow[t]{2}{*}{0.208} \\
\hline & + & $167.55(21.43)$ & \\
\hline \multirow[t]{2}{*}{ Family history of CAD } & - & $161.55(21.57)$ & \multirow[t]{2}{*}{0.118} \\
\hline & + & $168.90(14.60)$ & \\
\hline
\end{tabular}

CAD coronary artery disease.

Data represented as median (interquartile range).

* $\mathbf{p}<\mathbf{0 . 0 5}$ 


\section{Table 3. Correlation between baseline characteristics and MNV levels.}

\begin{tabular}{|c|c|c|}
\hline \multirow[t]{2}{*}{ Variables } & \multicolumn{2}{|l|}{ MNV levels, arbitrary units } \\
\hline & $\mathrm{r}$ & $\mathrm{p}$ value \\
\hline Age, years & $-0.060 * *$ & 0.529 \\
\hline Body mass index, $\mathrm{kg} / \mathrm{m}^{2}$ & $-0.097 * *$ & 0.417 \\
\hline Serum creatinine, $\mathrm{mg} / \mathrm{dL}$ & 0.141 & 0.135 \\
\hline Fasting blood glucose, $\mathrm{mg} / \mathrm{dL}$ & 0.192 & 0.086 \\
\hline LDL-cholesterol, mg/dL & 0.164 & 0.118 \\
\hline HDL-cholesterol, mg/dL & 0.078 & 0.489 \\
\hline Triglyceride, $\mathrm{mg} / \mathrm{dL}$ & -0.007 & 0.949 \\
\hline Total cholesterol, $\mathrm{mg} / \mathrm{dL}$ & 0.100 & 0.405 \\
\hline Hemoglobin, g/dL & $0.095 * *$ & 0.314 \\
\hline White blood cell count, $x 10^{3} / \mu \mathrm{L}$ & 0.048 & 0.616 \\
\hline Platelet count, $\times 10^{3} / \mu \mathrm{L}$ & -0.011 & 0.905 \\
\hline Peak CK-MB, ng/mL & 0.527 & $0.008^{*}$ \\
\hline Peak troponin-I, ng/ml & 0.478 & $0.018^{*}$ \\
\hline $\mathrm{CRP}, \mathrm{mg} / \mathrm{L}$ & 0.308 & $0.002 *$ \\
\hline LVEF, \% & -0.185 & 0.064 \\
\hline
\end{tabular}

\section{Table 4. Multivariate regression analysis for identifying associates of acute coronary syndrome.}

\begin{tabular}{|c|c|c|c|c|c|c|}
\hline \multirow[t]{3}{*}{ Variables } & \multicolumn{6}{|c|}{ Acute coronary syndrome vs. normal coronary arteries } \\
\hline & \multicolumn{3}{|c|}{ Univariate regression } & \multicolumn{3}{|c|}{ Multivariate regression } \\
\hline & OR & $95 \% \mathrm{CI}$ & $\mathrm{p}$ value & OR & $95 \% \mathrm{CI}$ & $\mathrm{p}$ value \\
\hline Family history of CAD n (\%) & 1.667 & $0.729-3.808$ & 0.226 & - & - & - \\
\hline Mean neutrophil volume, arbitrary units & 1.450 & $1.282-1.640$ & $<0.001 *$ & 1.408 & $1.242-1.596$ & $<0.001 *$ \\
\hline C- reactive protein $(\mathrm{mg} / \mathrm{L})$ & 1.119 & $1.051-1.191$ & $<0.001 *$ & 1.092 & $1.010-1.182$ & $0.028 *$ \\
\hline LVEF, \% & 1.000 & $0.992-1.008$ & 0.985 & - & - & - \\
\hline
\end{tabular}

There is scarce data investigating the morphological changes in neutrophils that occur in the setting of ACS. van Hout et al. have compared MNV between STEMI patients $(\mathrm{n}=84)$ and stable angina patients $(\mathrm{n}=209)$, as well as an animal model of ACS(23). Flow cytometry analysis has revealed that higher MNV was probably due to increased banded and hyper segmented neutrophils. In addition, mature neutrophils also had a higher MNV after MI compared to baseline, suggesting that MNV is increased post-ACS due to neutrophil activation (23). 


\section{LIMITATIONS OF THE STUDY}

There are several limitations of this study. This study lacks causality and reveals only an association. Second, the size of the study population has limited several statistical analyses to reach statistical significance.

\section{CONCLUSION}

Our findings suggest that $\mathrm{MNV}$ is elevated in ACS in the lack of quantitative changes in WBC count. The spectrum of morphological changes in neutrophils, expressed in terms of MNV, merits further evaluation for its predictive value for early diagnosis of ACS and the extent of post-MI ischemic damage.

\section{REFERENCES}

1. http://www.who.int/news-room/factsheets/detail/the-top-10-causes-of-death [Available from: http://www.who.int/newsroom/fact-sheets/detail/the-top-10-causes-ofdeath

2. Thygesen K, Alpert JS, Jaffe AS, Chaitman BR, Bax JJ, Morrow DA, et al. Fourth universal definition of myocardial infarction (2018). European heart journal. 2018.

3. Pellizzon GG, Dixon SR, Stone GW, Cox DA, Mattos L, Boura JA, et al. Relation of admission white blood cell count to long-term outcomes after primary coronary angioplasty for acute myocardial infarction (The Stent PAMI Trial). The American journal of cardiology. 2003;91(6):729-31.

4. Tamura A, Watanabe T, Nasu M. Association between neutrophil counts on admission and left ventricular function in patients successfully treated with primary coronary angioplasty for first anterior wall acute myocardial infarction. The American journal of cardiology. 2001;88(6):678-80.

5. Sabatine MS, Morrow DA, Cannon CP, Murphy SA, Demopoulos LA, DiBattiste PM, et al. Relationship between baseline white blood cell count and degree of coronary artery disease and mortality in patients with acute coronary syndromes: a TACTICS-TIMI 18 (Treat Angina with Aggrastat and determine Cost of Therapy with an Invasive or Conservative Strategy-
Thrombolysis in Myocardial Infarction 18 trial)substudy. Journal of the American College of Cardiology. 2002;40(10):1761-8.

6. Huang G, Zhong XN, Zhong B, Chen YQ, Liu $\mathrm{ZZ}, \mathrm{Su} \mathrm{L}$, et al. Significance of white blood cell count and its subtypes in patients with acute coronary syndrome. European journal of clinical investigation. 2009;39(5):348-58.

7. Tamhane UU, Aneja S, Montgomery D, Rogers EK, Eagle KA, Gurm HS. Association between admission neutrophil to lymphocyte ratio and outcomes in patients with acute coronary syndrome. The American journal of cardiology. 2008;102(6):653-7.

8. Machado GP, Araujo GN, Carpes CK, Lech M, Mariani S, Valle FH, et al. Comparison of neutrophil-to-lymphocyte ratio and mean platelet volume in the prediction of adverse events after primary percutaneous coronary intervention in patients with ST-elevation myocardial infarction. Atherosclerosis. 2018;274:212-7.

9. Monteiro Junior JGM, Torres DOC, da Silva M, Martins CMH, da Silva IK, do Nascimento MEM, et al. Prognostic value of hematological parameters in patients with acute myocardial infarction: Intrahospital outcomes. PloS one. 2018;13(4):e0194897.

10. Ayca B, Akin F, Celik O, Yuksel Y, Ozturk D, Tekiner F, et al. Platelet to lymphocyte ratio as a prognostic marker in primary percutaneous coronary intervention. Platelets. 2015;26(7):63844.

11. Uyarel H, Ergelen M, Cicek G, Kaya MG, Ayhan E, Turkkan C, et al. Red cell distribution width as a novel prognostic marker in patients undergoing primary angioplasty for acute myocardial infarction. Coronary artery disease. 2011;22(3):138-44.

12. Adam AM, Rizvi AH, Haq A, Naseem R, Rehan A, Shaikh AT, et al. Prognostic value of blood count parameters in patients with acute coronary syndrome. Indian heart journal. 2018;70(2):23340.

13. Carbone F, Nencioni A, Mach F, Vuilleumier N, Montecucco F. Pathophysiological role of neutrophils in acute myocardial infarction. Thrombosis and haemostasis. 2013;110(3):50114. 
14. Li DB, Hua Q, Liu Z, Li J, Xu LQ, Wang S, et al. Association between inflammatory mediators and angiographic morphologic features indicating thrombus formation in patients with acute myocardial infarction. Chinese medical journal. 2009;122(15):1738-42.

15. Kurup RP, S. Neutrophils in acute coronary syndrome. EMJ Cardiol. 2017;5(1):9.

16. Baysal E, Burak C, Cay S, Aksu T, Altintas B, Yaylak B, et al. The neutrophil to lymphocyte ratio is associated with severity of rheumatic mitral valve stenosis. J Blood Med. 2015;6:1516.

17. Baysal E, Cetin M, Yaylak B, Altntas B, Altndag $\mathrm{R}$, Adyaman $\mathrm{S}$, et al. Roles of the red cell distribution width and neutrophil/lymphocyte ratio in predicting thrombolysis failure in patients with an ST-segment elevation myocardial infarction. Blood Coagul Fibrinolysis. 2015;26(3):274-8.

18. Bagdasaryan R, Zhou Z, Tierno B, Rosenman D, $\mathrm{Xu}$ D. Neutrophil VCS parameters are superior indicators for acute infection. Lab Hematol. 2007;13(1):12-6.

19. Bhargava M, Saluja S, Sindhuri U, Saraf A, Sharma P. Elevated mean neutrophil volume+CRP is a highly sensitive and specific predictor of neonatal sepsis. Int J Lab Hematol. 2014;36(1):e11-4.

20. Mardi D, Fwity B, Lobmann R, Ambrosch A. Mean cell volume of neutrophils and monocytes compared with C-reactive protein, interleukin-6 and white blood cell count for prediction of sepsis and nonsystemic bacterial infections. Int $\mathbf{J}$ Lab Hematol. 2010;32(4):410-8.

21. Zhu Y, Cao X, Zhang K, Xie W, Xu D, Zhong C. Delta mean neutrophil volume (DeltaMNV) is comparable to procalcitonin for predicting postsurgical bacterial infection. J Clin Lab Anal. 2014;28(4):301-5.

22. Lam SW, Leenen LP, van Solinge WW, Hietbrink F, Huisman A. Comparison between the prognostic value of the white blood cell differential count and morphological parameters of neutrophils and lymphocytes in severely injured patients for 7-day in-hospital mortality. Biomarkers. 2012;17(7):642-7.
23. van Hout GP, van Solinge WW, Gijsberts CM, Teuben MP, Leliefeld PH, Heeres M, et al. Elevated mean neutrophil volume represents altered neutrophil composition and reflects damage after myocardial infarction. Basic research in cardiology. 2015;110(6):58. 